\title{
INTERNATIONAL FINANCIAL REPORTING STANDARD NO 15 "CUSTOMER AGREEMENTS" IN THE CONSTRUCTION INDUSTRY
}

\author{
Anna Kasperowicz \\ Wrocław Univeristy of Economics, Wrocław, Poland \\ e-mail: anna.kasperowicz@ue.wroc.pl
}

ORCID: 0000-0001-9560-6360

(C) 2018 Anna Kasperowicz

This is an open access article distributed under the Creative Commons Attribution-NonCommercial-NoDerivs license (http://creativecommons.org/licenses/by-nc-nd/3.0/)

DOI: 10.15611/fins.2018.3.06

\begin{abstract}
The paper presents the features of the construction industry and the ways of organising investment processes, as well as the methods for the valuation of the services implemented within its scope. The individual valuation methods were assigned to the applicable provisions of Polish balance sheet law and the International Financial Reporting Standard No 15 "Revenues from contracts with customers" in force since 2018. On the basis of a practical example, there was illustrated the achieved financial result of a company providing installation services as a subcontractor in view of all the possible valuation methods. The author presented and evaluated the anticipated effects of the new standard's entry into force, and in conclusion presented a selection of the valuation methods for the services performed in this industry, which is complicated and has a decisive impact on the amount of profits and losses of the financial results presented in the account.
\end{abstract}

Keywords: International Financial Reporting Standard No 15 "Revenues from contracts with customers", construction industry.

\section{Introduction}

Construction is a branch of the economy that deals with the creation of objects that meet all of the following three conditions [Witkowski 2007, p. 175]:

- they are located in the field and set on the ground,

- they have a permanent character,

- they were built to satisfy specific human needs.

The implementation of construction works involves the need to incur large expenditure, engage the contractor for a relatively long period, which is difficult to specify before starting work in connection with the high risk associated with the implementation of the construction services. The created objects have a unique 
character and are built according to a specific project which is often subject to changes during implementation. These features of construction production make it a difficult technological activity in terms of technology. It is also difficult for financial and accounting departments which have an obligation to prepare financial statements for such entities. The valuation of services in progress requires making subjective judgments and is therefore always risky. In Polish accounting (balance sheet) law and in international solutions, entries were made regarding the valuation of such services which by 2017 were analogous. Since 2018 the International Financial Reporting Standard No 15 "Revenue from contracts with customers" has been in force, which means that the existing national balance sheet laws regarding the valuation of construction services will not overlap with international standards.

The aim of the study is to present the anticipated effects of the International Financial Reporting Standard No 15 "Revenue from contracts with customers" in the construction industry, in particular the changes regarding the selection of valuation methods. The study uses a comparative analysis method supported by the synthesis method.

\section{Characteristics of the construction industry}

Construction is an activity consisting in building new facilities and making changes to existing facilities. It is one of the nineteen sections of the national economy, and is closely related to other departments and at the same time heavily dependent on them. Development in the industry is often identified with economic development, because construction through the thread of dependence with other sectors of the economy allows the development of production activities as well as satisfying individual and collective needs. According to the Deloitte Report, in 2014, construction companies generated $7.4 \%$ of GDP directly, and together with indirect effects as much as $16.8 \%$ of GDP [The role of the materials sector...]. In comparison to other sectors of the economy, this one is considerably diverse and fragmented, and small and mediumsized enterprises play a significant role in it [Zawadzki 2002, p. 8].

In the Polish Classification of Goods and Services, the effects of services provided within the construction industry have been classified in section $\mathrm{F}$ CONSTRUCTION OBJECTS AND CONSTRUCTION WORKS. This section includes:

- Section 41 - buildings and construction works related to the construction of buildings.

- Section 42 - buildings and general construction works related to the construction of civil engineering structures.

- Section 43 - specialised construction works.

In section 41, there are residential and non-residential buildings as well as construction works related to the erection of residential and non-residential buildings. 
Section 42 buildings and general construction works, relates to the construction of civil engineering, i.e. roads, rail, underground railway, bridges, tunnels, pipelines, telecommunications lines, transmission pipelines, distribution networks, power stations, wharves, ports, dams, locks and related objects, hydrotechnical constructions, mining, sports and recreation facilities, together with general construction works related to their erection. In section 43 , all the specialised construction works have been grouped, such as demolition of construction works, preparation of land for construction, preparation of electrical installations, plumbing, drainage, heating, ventilation, air conditioning, gas installations, insulation, plastering, painting, glassworks, concrete, construction joinery, decorative elements, structures and roofing, as well as steel structures and prefabricated elements.

The specificity of this industry is the uniqueness of the construction object, whose special character is determined by its individual characteristics and the external conditions of its construction. The basic features of construction production are [Rytel 2007, pp. 162-168]:

1. Seasonality - dependence of the contract fulfilment on weather conditions.

2. Immovability of the production site and the resulting deconcentration of construction production - the final construction product is created at the place of its future use, which necessitates the relocation of the construction company's resources.

3. Personnel fluctuation - results from the seasonality of the works performed and the spatial distribution of works.

4. Durability - the construction of a building usually takes more than a year.

5. Longevity of building objects - the final product created in this section of the economy is usually one of the most durable man-made products.

6 . The unique character of the object - the effects of the construction works are unrepeatable and carried out according to a specific project.

7. Technical conservatism - on the one hand, the increasingly sophisticated technologies used, on the other hand, the necessity to carry out renovations forces construction units to use already obsolete work techniques.

8. Sensitivity to the business cycle - this industry is closely related to the overall condition of the country's economy and reacts to its changes the most quickly.

9. Significant size and huge weight of construction objects.

10. Random nature of building construction time - it is difficult to predict the total construction time because the construction depends on a number of difficult to control factors, in particular the implementation of orders for a large amount of construction materials, staff turnover and weather conditions.

11. Significant costs of construction investments - as a rule, orders in this industry are characterised by high cost consumption.

12. Generation of a large amount of waste-construction is inseparably connected to the creation of a large amount of material side effects, which the contractor must adequately secure. 
13. Relatively low entry threshold - construction work does not require investing a lot of capital, therefore it is relatively easy to start a business in this industry.

The basic characteristic of construction works is performing them at the place of the final use. Therefore the scope of the work and the place of its implementation is determined by the ordering party. The contractor fulfils the order at the place designated by the ordering party. The investment process, especially for large enterprises, can be organised in various ways. The classic way of running large investments consists in employing a general contractor by the contracting authority (investor). The general contractor carries out and organises the whole investment process from performing the work with their own resources, through employing subcontractors for works that they cannot perform themselves, through making payments to subcontractors, until the completion on the investment and its approval by the investor. The general contractor makes payments to subcontractors with funds received from the ordering party. In connection with art. $6471 \S 5$ of C.C. [Civil code 1964], the investor bears joint liability together with the general contractor for payment of remuneration for construction works performed by the subcontractor. On the basis of this provision, in the event of the general contractor's failure to pay, the subcontractor has the right to make a direct claim for the payment of remuneration to the investor and the investor cannot be released from joint liability. Thus the formulated liability is extremely severe and involves the risk of double payment by the contracting party - first in the form of remuneration for the main contractor and then remuneration for the subcontractor - if the main contractor did not pay the subcontractor despite receiving remuneration from the investor. Thus, making a remittance transfer to the main contractor does not release the investor from liability for payment to the subcontractor. Based on Art. $366 \S 2$ of C.C. [Civil code 1964] joint liability of the investor takes place up to the satisfaction of the creditor (subcontractor). In this regard, investors often use so-called packet management for their security. This model of investment implementation consists in employing a suitable company to carry out an investment that has no legal authority as the main contractor, and only manages the investment process on behalf of the investor. Such a company is obliged to divide investments into appropriate packages, and then assign them to individual external entities (subcontractors), accept the fulfilled order on behalf of the ordering party and ask the ordering party to make payments for the works performed. The cash flow for the completed packages does not pass through the employed company. Funding is direct and goes from contracting authority to specific subcontractors. Responsibility for the construction site is not transferred to the management company, but to the investor.

\section{New set of valuation methods according to IFRS 15}

The literature on the subject distinguishes four methods:

- issued invoices, 
- contract fulfilment,

- stage completion,

- zero result.

According to the Polish accounting (balance sheet) law, the valuation of construction services being in progress is made according to two permitted methods. The first is the advancement method, the second is the zero-result method, which can alternatively be used if the former cannot be employed. The solution adopted by Poland in this matter stood in accordance with the provisions of International Accounting Standard 11 "Contracts for construction services". A new standard has been in force since 2018, replacing IAS 11 and 18 "Revenues". In the new solutions the transaction approach has been applied when recognising the income. In the standard it is assumed that in a result of signing an agreement both sides need to fulfil the required obligation of a specific action towards the other side. This means that both sides have obligations as well as rights : where the individual is in the right, the client is obliged (to pay) and vice versa (described in: [Kasperowicz, Mazur 2017, p. 74]). An illustrative comparison of the [Deloitte_Przewodnik_MSSF_2018_FINAL. pdf (1,45 MB)]. MSSF 15 and the Polish solutions has been presented in the practical guide after MSSF 15. After the analysis of the records of MSSF 15 it can be stated that the range of the methods of valuation has been extended with the method of making a contract.

The provisions of the new standard added one more method to the existing one. Figure 1 presents the valuation methods described in the literature on the subject, entered into the areas of applicable legal and professional regulations.

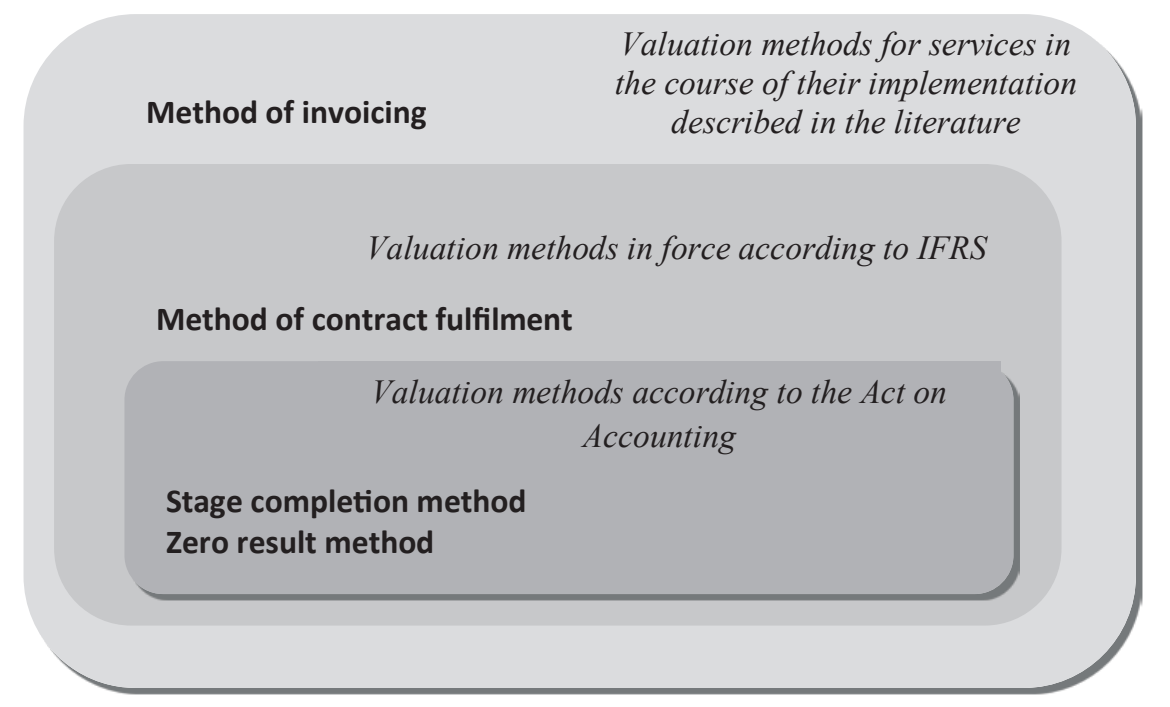

Fig. 1. Valuation methods and areas of their validity

Source: own. 
As seen in the presented figure, the method of issued invoices is currently not allowed as a method of valuation as of the balance sheet date in the analysed legal and professional regulations. According to IFRS 15, three alternative methods may be used for the valuation (contract fulfilment, stage completion, zero result), while the spectrum of application for the last two is the smallest and currently only applies to the Act on Accounting.

The method of issued invoices is the simplest and most convenient approach to the valuation issue. It is based on the assumption that all works can be divided into separate stages defined in the works acceptance schedule. Then, separated fragments of completed work stages are sold and invoiced as individual parts of the whole. The invoiced amount is revenue within the meaning of the tax law. This method, however, due to its numerous defects, was not accepted either in the statutory provisions or in the professional regulations regarding accounting.

In the method of contract fulfilment, the finished and received effect included in the contract is the subject of the sale. This approach means that during the performance of the works, neither income nor costs related to the implementation of the investment are recognised in the profit and loss account. The result categories are disclosed in full only after the end of the contract. This method implements the principle of prudent valuation to its greatest extent, because the result is revealed only after the approval of the final effect by the ordering party.

The provisions of the new IFRS 15 regarding the selection of the valuation method cause the decision-making in this matter to depend on the results of the analysis of the transfer of control over the contracted object. In paragraph 38 of the standard, in order to facilitate the identification of this moment, the following conditions were proposed for analysis:

1) the entity possesses the current right to payment,

2) the customer possesses a legal title,

3) the component has been physically transferred and the recipient is able to manage the use and obtaining of economic benefits and has the right to restrict the access of other people,

4) the customer bears the risks and benefits of ownership,

5) the customer has taken over the component.

In a situation where the material effect of the fulfilment of the order by the contractor is transferred after completion of the work after the protocol, the contract fulfilment method will be applied.

The use of the stage completion method is based on the fact that the revenues of a given contract are recognised in proportion to the progress of work. A prerequisite for its use is the possession of reliable estimates and the ability to reliably estimate the progress of works.

The level of advancement can be measured in the following ways [Costs in managing a small and medium service enterprise 2007, p. 61] 
- the share of costs incurred from the date of fulfilment of the contract till the date of determining the revenue in the total cost of the service,

- the number of hours devoted directly to the service,

- based on the measurement of completed work,

- by using contractual billing units (e.g. a running kilometre),

- by the linear method,

- by using other analogue billing units, e.g.

- hours of machine work,

- value or quantity of materials used.

This method corresponds to the provisions of IFRS 15 regarding the gradual transfer of control. According to the provisions of IFRS 15, gradual transfer of control during performance of a service takes place when at least one of the following conditions is met:

- the customer simultaneously receives and draws benefits from the unit's performance as it fulfils its commitment,

- as a result of the fulfilment of the obligation, an asset is created or improved, and control over it - as it arises or improves - is exercised by the customer,

- as a result of the fulfilment of the obligation, a component is created without an alternative application for the entity, and the entity is entitled to the enforceable right to payment for the services performed so far.

After determining that the entity transfers control during the course of work, it recognizes the revenues for each separate service provided under the contract, using the stage completion method.

If an enterprise cannot reliably determine the degree of service completion, then it applies the zero-result method which limits the statement of revenue to the amount of costs incurred which are likely to be recovered from the ordering party. In accordance with the principle of prudence, no profits from the contracts in progress are recognised in the profit and loss account. On the one hand, the costs incurred are recognised as they are incurred, on the other hand, there are shown revenues only up to the amount of costs incurred, for which there is a probability of payment by the ordering party. The application of this method results in not showing a profit or disclosing a loss in the case of services for which the entity anticipates a loss. The achieved profit of the contract is disclosed only after the completion of all work. In the income statement, the entity's activity is reflected by revealing the costs and corresponding revenues determined according to the zero-result method. The zero-result method is used in the early phases of the service implementation, when it is difficult to estimate the results of the order. 


\section{Anticipated effects of applying IFRS 15 in the scope of selecting methods for the valuation of services provided, using the example of a company providing installation services}

The construction and installation services under analysis were carried out by a construction company operating on the Lower Silesian market since 1968. It is one of very few companies in the construction industry that survived the economic changes. The transformation of a business unit into a commercial company occurred in the early nineties. The surveyed enterprise provides electrical and telecommunications installations mainly in the area of housing and general construction. The company provides the following services: design and assembly of electrical, telecommunications, computer, and power supply networks as well as intercoms and alarm systems. Most of the activities performed for the implementation of the aforementioned services were classified in the PCGS in section 43 as specialised construction works. An inherent element of installation services is of course design, classified in section 74 as an activity in the field of construction, urban and technological design.

An economic entity providing construction services may, through the selection of valuation methods for services being in progress as of the balance sheet date, affect the presentation of the financial result in the financial statements. The impact of the valuation on the enterprise' financial result is of a two-stage nature:

- the first stage has a direct impact on the result from the main operating activity of the economic entity, i.e. on the result on sales,

- the second stage concerns changes in assets and provisions for tax-free income, which in turn affect the net result of the business unit.

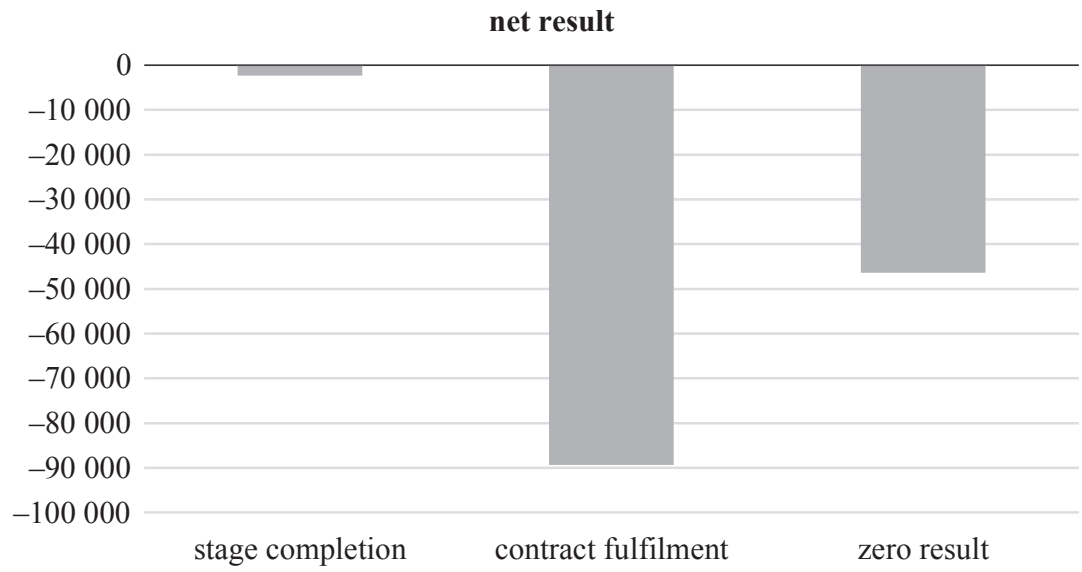

Fig. 2. Financial results according to individual valuation methods

Source: own. 
In the analysed period, the unit implemented 12 installation services in newly built housing facilities. At the end of 2015, the unit evaluated all services being implemented using the stage completion method, revealing a small loss (approximately 2,000 PLN). See Figure 2.

Had the entity applied the contract fulfilment method, the disclosed loss would be 38 times greater. The application of the zero result method would also reveal a fairly large loss, although a lesser one than in the case of the contract fulfilment method. The effect of the contract performance method would be the postponement of the results achieved in connection with the implementation of specific works, up to the moment of their completion and the transfer of the financial effect to the recipient. The result presented as the effect of the zero result is a kind of indirect solution between the stage completion method and contract fulfilment method. The structure of the established results is presented in Figure 3.

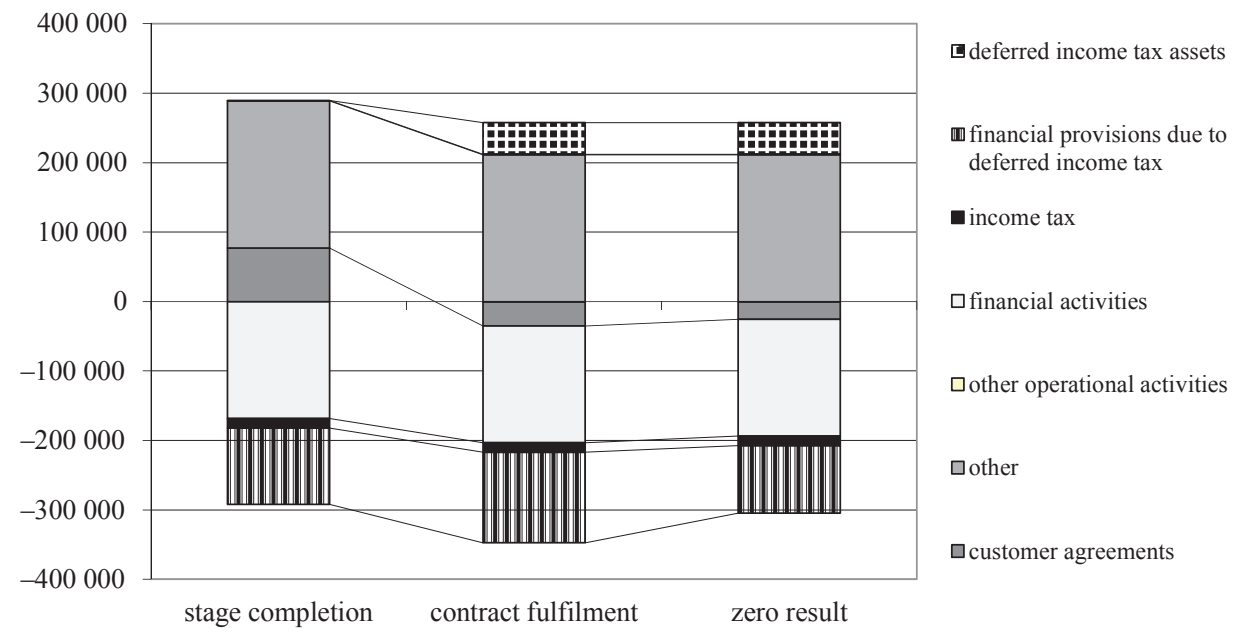

Fig. 3. Structure of determined financial results according to individual valuation methods Source: own.

Figure 3 shows that as part of the result determined with the stage completion method, the element concerning contracts with customers is positive, while in other cases it deepens the determined loss. The losses incurred as part of the contract fulfilment and the zero result methods are the consequence of the losses of individual services. In the method of contract fulfilment, the outcome of the contract has been disclosed, the implementation of which had just been completed. Unfortunately, the result of this agreement was negative. The loss under the zero-result method is the accumulation of the results of three contracts, two of which were negative. The last result is positive and its source is an inflated invoice in relation to the costs incurred. 
The provisions of the new standard are quite general and leave many issues to the decision of the business unit. The issue of transferring control can also be debatable. In a situation when the investment is carried out in a standard manner, i.e. the main contractor is appointed and they control the construction site, the unit providing installation services fulfil the order in the area controlled by the main contractor and the transfer of control takes place successively. In such a situation, it would be reasonable to apply the stage completion method. On the other hand, if the unit acts directly at the request of the investor, the transfer of control takes place after the contracting party takes over the construction site. Then it is reasonable to use the method of contract fulfilment.

The necessity to use the contract fulfilment method instead of the stage completion method is disadvantageous from the unit's point of view, because it forces it not to reveal the activity in the profit and loss account during the duration of the contract. Recognition of the result takes place only in the case of the completion of the contract and acceptance of services by the ordering party.

\section{Conclusion}

The presented considerations show that the choice of the valuation method has a decisive influence on the financial results in companies from the construction industry. This result stems from the application of the valuation method and the deferred income tax assets and provisions accrued due to its application. Thus, the final amount of the net financial result is quite difficult to determine and laborious. In the analysed case, for the entity that will be preparing its financial statements the year 2018 will bring about major changes. Above all, numerous issues related to the choice of the method become even more discretionary than before. It is up to the entity to choose the method in the context of transferring control. However, the construction process is quite complex, hence the decision-making conditions are also complicated. In most cases, in the construction industry when the subject of the contract will be a specific construction project carried out at the request of the investor by the general contractor, it will be necessary to apply the contract fulfilment method. In the case of subcontractors, the matter becomes complicated and the final decision depends on the analysis of the specific case.

In general, the application of the contract fulfilment method will delay the results of the work being carried out and will often be unable to cover management costs with revenues generated in other activities, such as the remaining operational and financial ones. 


\section{Bibliography}

Civil code, Journal of Laws 1964, no. 16, item 93.

Costs in Managing a Small and Medium Service Enterprise, 2007, ed. R. Kowalak, Publishing House of the Oskar Lange Academy of Economics in Wroclaw, Wroclaw.

Deloitte_Przewodnik_MSSF_2018_FINAL.pdf (1,45 MB).

International Financial Reporting Standards, 2016, AAP, Warsaw.

Kasperowicz A., Mazur A., 2017, Revenue Recognition in Accounting - New Approach from 2018 in Financial Reporting and Auditing, Foundation of the University of Economics in Krakow, Krakow.

Polish Classification of Goods and Services, http://stat.gov.pl/Klasyfikacje/doc/pkwiu_15/pdf/PKWiU-2015-schemat_tekst_ujednolicony.pdf (access December 20, 2017).

Rytel O., 2009, The specificity of construction production, Scientific Papers of the Academy of Podlasie in Siedlce, no. 83 Series: Administration and Management.

The role of the building materials sector, Deloitte, http://www.dlabudownictwa.pl/wp-content/uploads/2016/04/5.-Rola-sektora-materia\%C5\%82\%C3\%B3w-budowlanych-i-budownictwa-R.Antczak.pdf.

Witkowski P., 2007, Progress and Modernity in Construction Technologies, WACETOB, Puławy.

Zawadzki E., 2002, Polish construction before joining the European Union, Study and Expertise Office, Parliamentary Publishing House, Warsaw.

\section{MIECDZYNARODOWY STANDARD SPRAWOZDAWCZOŚCI FINANSOWEJ NR 15 „UMOWY Z KLIENTAMI” W BRANŻY BUDOWLANEJ}

Streszczenie: W opracowaniu zaprezentowano cechy branży budowlanej i sposoby organizowania procesów inwestycyjnych, a także metody wyceny usług realizowanych w jej ramach. Dokonano przyporządkowania poszczególnych metod wyceny do obowiązujących przepisów polskiego prawa bilansowego oraz Międzynarodowego Standardu Sprawozdawczości Finansowej nr 15 „Przychody z umów z klientami” obowiązującego od 2018 roku. Na podstawie przykładu praktycznego zilustrowano osiągnięty wynik finansowy spółki świadczącej usługi instalacyjne jako podwykonawca w przekroju wszystkich możliwych metod wyceny. Zaprezentowano przewidywane skutki wejścia w życie nowego standardu i dokonano ich oceny. W zakończeniu zaprezentowano, że dobór metod wyceny dla usług realizowanych w tej branży jest skomplikowany i ma decydujący wpływ na wysokość prezentowanego w rachunku zysków i strat wyniku finansowego.

Słowa kluczowe: Międzynarodowy Standard Sprawozdawczości Finansowej nr 15 „Przychody z umów z klientami”, branża budowlana. 